\title{
HUBUNGAN KECERDASAN EMOSIONAL DENGAN HASIL BELAJAR PKn SISWA SMA NEGERI SIPAHUTAR TAPANULI UTARA
}

\author{
Oleh: \\ Lukman Pardede ${ }^{1)}$ \\ Dewi Lestari Pardede ${ }^{2)}$ \\ Universitas HKBP Nomensen, Medan ${ }^{1)}$ \\ STINDO Medan ${ }^{2)}$ \\ E-mail: \\ $\frac{\text { lukmanpardede1961@ gmail.com }}{{ }^{1)}}$
}

\begin{abstract}
The study was conducted to determine the significant relationship between emotional intelligence and Civics learning outcomes of students of SMA Negeri Sipahutar Tapanuli Utara in 2020. This type of research is correlational descriptive. The population in this study is all students of SMA Negeri Sipahutar Tapanuli Utara, consisted of 117 students. The sample used in this study is by using Krecji Table Sampling with a total of 5\% of the total population so that the number of samples is 90 people. The instrument in this study is a questionnaire consisting of 34 items that had 4 options (a, b, c, d) which have been tested for validity and reliability. The results of the normality test results of students' emotional intelligence data are normally distributed with the results of the calculation of $x 2$ hitung <x2table (59.175> 516). Normality data of student learning outcomes is normally distributed with the results of the calculation of $x 2$ hitung <x2tabel $(2,225>516)$. The results of the linearity test of emotional intelligence data with Civics learning outcomes are linear with the equation $\mathrm{Y}=0.535+0.878$ with Fhabel obtained $\mathrm{Fh}>\mathrm{Ft}(\mathrm{Fh}>\mathrm{Ft}(27.73>4.20$. Tendency test of students' emotional intelligence (Y) is categorized as moderate $31.11 \%$. 'Civics learning outcomes of students (Y) category tends to be moderate $\left(28.88 \%\right.$. The results of the product moment correlation test obtained are $\left(\mathrm{r}_{\text {count }}\right.$ $0.446)$ and $r$ table $=0.207$ then $r$ count $>r$ table $(0.446>0.207)$, then this shows that there is a significant relationship between emotional intelligence and Civics learning outcomes of students of SMA Negeri Sipahutar Tapanuli Utara in 2020. To test the significance level of the two variables above followed by a statistical test $\left(\mathrm{t}_{\text {test }}\right)$, it is obtained $\mathrm{t}_{\text {count }}=4.674$ and $\mathrm{t}$ table $=$ 1.661 then $t_{\text {count }}>t_{\text {table }},(4,674>, 1,661)$ because $t_{\text {count }}>t_{\text {table, }}$, this shows that there is a significant relationship between emotional intelligence and Civics learning outcomes of Sipahutar Tapanuli Utara Senior High School students in 2020, the hypothesis is accepted.
\end{abstract}

Keywords: Intelligence, Emotional, and Learning Outcomes

\begin{abstract}
ABSTRAK
Penelitian dilakukan untuk mengetahui hubungan signifikan antara kecerdasan emosional dengan hasil belajar PKn siswa SMA Negeri Sipahutar Tapanuli Utara Tahun 2020. Jenis penelitian ini adalah deskriptif korelasional. Populasi dalam penelitian ini adalah seluruh siswa SMA Negeri Sipahutar Tapanuli Utara.yang terdiri dari 117 siswa. Sampel yang digunakan dalam penelitian ini menggunakan pengambilan sampel tabel krecji dengan jumlah $5 \%$ dari jumlah populasi sehingga jumlah sampel ialah 90 jiwa. Instrumen dalam penelitian ini adalah angket yang terdiri dari 34 item yang memiliki 4 pilihan (a,b,c,d) yang telah diuji validitas dan reliabilitas. Hasil uji persyaratan normalitas data kecerdasan emosional siswa berdistribusi normal dengan hasil perhitungan $x^{2}$ hitung $<x^{2}$ tabel $(59,175>516)$.Data normalitashasil belajar siswa berdistribusi normal dengan hasil perhitungan $\mathrm{x}^{2}{ }_{\text {hitung }}<\mathrm{x}^{2}$ tabel
\end{abstract}


(2,225> 516). Hasil uji linearitas data kecerdasan emosional dengan hasil belajar PKn adalah linear dengan persamaan $\mathrm{Y}=0,535+0,878$ dengan $\mathrm{F}_{\text {tabel }}$ diperoleh $\mathrm{Fh}>\mathrm{Ft}(\mathrm{Fh}>\mathrm{Ft}(27,73>4,20$. Uji kecenderungan kecerdasan emosional siswa (Y) dikategorikan sedang31,11\%.`hasil belajar PKn siswa (Y) kategori cenderung sedang( 28,88\%..Hasil uji korelasi product moment yang diperoleh $_{1}\left(r_{\text {hitung }} 0,446\right)$ dan $r_{\text {tabel }}=0,207$ maka $r_{\text {hitung }}>r_{\text {tabel }}(0,446>0,207)$, maka hal ini menunjukkan ada hubungan signifikan antara kecerdasan emosional dengan hasil belajar PKn siswa SMA Negeri Sipahutar Tapanuli UtaraTahun 2020. Untuk menguji taraf signifikasi kedua variabel diatas dilanjutkan dengan uji statistik ( uji t) maka diperoleh $t_{\text {hitung }}=4,674$ dan $t_{\text {tabel }}=1,661$ maka $t_{\text {hitung }}>t_{\text {tabel }},(4,674>, 1,661)$ karena $t_{\text {hitung }}>t_{\text {tabel }}$ maka hal ini menunjukan ada hubungan yang signifikan antara kecerdasan emosional dengan hasil belajar PKn siswa SMA Negeri Sipahutar Tapanuli Utara Tahun 2020 diterima kebenarannya.

\section{Kata Kunci: Kecerdasan, Emosional, dan Hasil Belajar}

\section{PENDAHULUAN}

Tujuan pendidikan kewarganegaraan tidak hanya meningkatkan kemampuan intelektual saja namun nilai budaya, perilaku dan akhlak perlu ditanamkkan dalam peserta didik, sehingga proses pembelajaran dalam pendidikan itu hanya menghasilkan manusia yang berilmu tinggi namun juga manusia yang memiliki budi pekerti dan akhlak yang tinggi pula. Untuk ulasan tersebut maka diperlukan pendidikan kewarganegaraan yang memberikan pengetahuan norma-norma dan etika yang berazaskan pancasila.

Menurut Permendiknas no.22 Thn 2006 mengenai satuan pendidikan dasar dan menengah yang berisi standart isi.Pendidikan kewarganegaraan memiliki tujuan untuk peserta didik, sebagai berikut

a. Berinteraksi dengan bangsa lain dalam peraturan dunia secara langsung dengan memanfaatkan teknologi informasi dan komunikasi.

b. Berpartisipasi secara aktif, bertanggung jawab, dan bertindak secara cerdas dalam kegiatan bermasyarakat, anti korupsi ,berbangsa, dan bernegara.

c. Berpartisipasi secara aktif, bertanggung jawab, dan bertindak secara cerdas dalam kegiatan bermasyarakat, berbangsa, dan bernegara, serta anti korupsi. d. Berpikir secarakreatif, rasional dan kritis dalam menanggapi isu kewarganegaraan.

Proses pembelajaran pendidikan Kewarganegaraan dapat memuwujudkan saling terkaitnya sikap intelektual, objektif, etika moral dalam bermasayarakat. Hal ini akan menciptakan keselarasan anatara guru dan siswa.PendidikanKewarganegaraan dapat memfasilitasi penanaman pendidikan karakter pada siswa.Sejalan dengan tujuan pendidikan kewarganegaraan tersebut, maka pembelajaran PKn harus diterapkan sejak dini untuk menciptakan keselarasan antara guru dan siswa.

Sekolah merupakan bagian dari lembaga formal untuk mencapai pendidikan yang bermutu.Hal ini memberikan tingkat pendidikan yang efektif sehingga mengalami perubahan yang signifikan untuk membangun pendidikan yang menuju psikomotorik, kognitif, dan ketrampilan. Penunjang dalam sistem belajar mengajar dapat terlihat dari sistem pembelajaran yang dapat terlihat nyata pada hasil yang telah dicapai siswa siswi di sekolah.Menurut Diniati dan Mudjiono ( 2013:200 ): mengatakan bahwa: "hasil belajar merupakan proses untuk menentukan nilai belajar siswa melalui kegiatan penilaian dan/atau pengukuran hasil belajar".

Berdasarkan kutipan di atas, hasil belajar adalah merupakan proses untuk menentukan nilai belajar siswa melalui kegiatan pengukuran hasil belajar.proses 
belajar mengajar untuk mencapai tujuan pendidikan merupakan bagian perubahan yang di upayakan dalam pembelajaran.Disini guru berusaha untuk meningkatkan sistem pembelajaran yang menyenangkan dan membangkitkan kemauan belajar siswa serta memeproleh hasil belajar yang baik, tinggi, berkualitas, sesuai dengan Kurikulum yang berlaku dan memenuhi Standart Kriteria Ketuntasan Minimal serta sesuai dengan Undang Undang Pendidikan.

Namun pada kenyataannya yang terjadi di lapangan berbeda dengan harapan.Masalah mengenai hasil belajar dialami SMANegeri Sipahutar Tapanuli Utarakhusunya dalam pembelajaran PKn di sekolah. Peneliti telah melakukan refleksi melalui data observasi, dan data dokumen ditemukan masalah, bahwa pelaksanaan pembelajaran PKn yang di persiapkan oleh guru sudah sesuai dengan standar prosesnya namun seringkali apa yang telah di persiapkan tidak mendapatkan hasil belajar yang kognitif yang sesuai batas tuntas. Sebagai proses belajar mengajar bisa dirasakan dari kemonukasi guru dan siswa. Apabila kita lihat dari siswa, siswa mengikuti sistem pembelajaran di kelas dengan memberikan respon berupa pertanyaan atau menjawab pertanyaan guru.hal ini membantu guru dapat mengetahui siswa yang aktif dan pasif. akan Teteapi, disini guru harus bekerja esktra keras karena harus mengajar secara objektif karena dapat memberikan perhatian yang merata tanpa meilihat latar belakang keluarga atau aktif pasifnya siswa.Jika guru belum melibatkan siswa secara aktif, terlepas dari guru yang sudah mencoba menerapkan namun rendah dari partisipasi siswa.

Berdasarkan hasil wawancara yang diperoleh peneliti pada mata pelajaran PKn SMA Negeri Sipahutar Tapanuli Utara, hasil belajar yang diperoleh siswa tergolong masih rendah.Masalah tersebut di tunjukkan dari daftar nilai hasil belajar ujian akhir semester ganjil 2019/2020 yang menunjukkan sebagian dari siswa memiliki nilai dibawah nilai KKM dan mata pelajaran PKn di anggap membosankan dan tidak menyenangkan.

Kecerdasan emosi adalah bekal penting anak dalam meraih kesuskesan di kehidupan mendatang, sebab sebagai generasi penerus banga akan selalu dihapkan dengan tantangan perkembangan zaman baik akademis maupun tidak. Dengan demikian akan memtu siswa dan guru saling intropeksi diri ke depannya.Hal tersebut perlu mendapat perhatian orang tua, guru dan sekolah untuk tercapainya hasil belajar siswa secara optimal.

Banyak faktor penyebab hasil belajar PKn rendah yaitu kecerdesaan semosional yang tidak stabil atau rendah. Peneliti akan melalukan observasi di sekolah penelitian untuk melihat hubungan kecerdasan emosional terhadap hasil belejar siswa.

(Uno, 2006: 68): "Kecerdasan emiosional merupakan suatu kamampuan untuk menghadapi suatui yang frustasi, memberikan motifasi diri, suasana hari sehiingga jauh dari bebas seteres".

Stein dan E. Book dalam Uno (2006: 69): "kecerdsan emosinal merupakan pengendalian suatu perasaan, mengembangkan sikap untuk membantu pikiran jauh dari emosional dan dapat memahami suatu makna perasaan dari emosional dan secara intelek.

\section{TINJAUAN PUSTAKA}

\section{Kecerdasan emosional}

\section{a. Pengertian Emosional \\ Kecerdasan}

Kata kecerdasan Emosional terdiri dari dua kata "kecerdasan" dan "Emosional".Sebelum mengetahui arti kecerdasan emosional secara integral terlebih dahulu mengetahui arti kecerdasan emosional secara terpisah.

Menurut Kamus Besar Bahasa Indonesia kecerdasan yaitu kesempurnaan akal budi seperti; kepandaian, ketajaman pikiran, sedangkan kata kecerdasan menurut 
kamus psikologi yaitu kemampuan menghadapi dan menyesuaikan diri terhadap situasi baru secara tepat dan efektif.

Beberapa tokoh masingmasing memiliki pengertian yang berbeda tentang kecerdasan. Bischof dan HeidenRich mengemukakan definisi intelegensi dengan pengertian yang sama yaitu: Intellegience refers to the ability to learn and to utilize what has been learned in adjuting to unfamiliar situations, or in the solving of problems. (intelegensidalam

kemampuan berpikir atau emosional akan mengkaitkan dengan sistem belajar mengajar untuk menyesuaikan hasil dari situasi yang tidak dikenal untuk mencapai kemampuan pemecahan masalah)

Feldam dalam Hamzah Uno (59) :

Kemampuan

memahami dunia, berpikir secara rasional, dan menggunakansumber secara efektif pada saat dihadapkan dengan tantangan.

Henmon dalam Hamzah Uno (59) :suatu kemampuan untuk memahami daya diri.

Berdasarkan kutipan di atas dapat disimpulkan, kecerdasan adalah kemampuan yang dimiliki seseorang dalam memahami lingkungan atau alam sekitar serta berpikir rasional guna menghadapi tantangan hidup serta dapat memecahkan berbagai problem yang dihadapi.

Emosional, kata emosi berasal dari movere, yang berarti kata kerja dalam bahasa latin yaitu menggerakkan atau bergerak, sehingga dapat disimpulkan emosi merupakan suatu gerakan atau mengeluarkan perasaan. Emosi dalam Kamus Besar Bahasa Indonesia (KBBI) di definisikan sebagai (1) luapan perasaan yang berkembang dan surut dalam waktu singkat; (2) keadaan dan reaksi psikologis dan fisiologis.

Menurut Goleman dalam uno (2006: 64) emosi merupakan suatu kegaiatan untuk mengelola perasaan, nafsu dan pikiran.Setiap keadaan yang meluapluap oleh karna itu, emosi merujuk pada suatu perasaan dan pikiran-pikiran khasnya, suatu keadaan biologis, psikologis, dan serangkaian kecendrungan untuk bertindak.

Goleman dalam Uno (2006: 64) mengungkapkan bahwa ada ratusan emosi yang berkaitan dengan mutasi, variasi, nuansya.Hasil teoretis menganai kelompok emosi untuk golongan besar harus lebih diperhatikan meskipun tidak semua sepakat tentang penggolongan ini. Golongan utama emosi dan beberapa anggota kelompoknya sebagai berikut,

a. Amarah, beringas, mengamuk, benci, marah, jengkel, kesal hati, terganggu, rasa pahit, berang, tersinggung , bermusuhan, dan barang kali yang paling hebat, dan tindakan keras

b. Kesedihan, pedih, sedih, muram, suram, melankolis, mengasihani,diri, kesepian, di tolak, putus asa, dan kalau menjadi psikologis, depresi berat.

c. Rasa takut: cemas, takut, gugup, khawatir, waswas, perasaan takut sekali, khawatir, waspada, sedihtidak tenang, ngeri, kecut, sebagai patologi, fobia dan panik

d. Kenikamatan: bahagia, gembira, ringan, puas, riang, senang, terhibur, bangga, kenikmatan indrawi, takjub, rasa terpesona, rasa puas, rasa 
terpenuhi, kegirangan luar biasa, senang, enang sekali, dan batas ujungnya, mania.

e. Cinta: penerimaan, persahabatan, kepercayaan, kebaikan hati, rasa dekat, bakti, hormat, kasmaran, kasih.

f. Terkejut: terkejut, terkesip, takjub, terpana.

g. Jengkel: hina, jijik, muak, mual, benci, tidak suka, mau muntah.

h. Malu: rasa salah, malu hati, kesal hati, sesal, hina, aib, dan hati hancur lebur.

Berdasarkan uraian tersebut, emosi adalah perubahan perilaku pada diri individu yang merujuk pada suatu ungkapan perasaan berupa rasa marah, bahagia, sedih, cinta, benci dan takut dan lain sebagainya.Emosi merupakan suatu keadaan psikologis, serta kecendrungan untuk bertindak akibat adanya situasi atau rangsangan tertentu.

Setelah meilihat dan memahami dari kecerdasan emosional maka harus dipahami bahwa kecerdasan emosional secara integral, Yaitu suatu hal untuk mengontrol emosional sehingga seseorang mampu menerima, mengelola, mengontrol emosi diri dan orang lain di sekitarnya. Sebab, emosional dapat mempengaruhi hubungan seseorang terhadap perasaan hubungan.

Selama ini kecerdasan intelektual (IQ) yang umumnya menjadi ukuran kecerdasan seseorang.Namun pada awal abad 1990 Daniel Goleman, memepopulerkan kecerdasan emosional (EQ).Kecerdasan ini tak kalah pentingnya dengan kecerdasan intelektual.Sebuah kemampuan untuk menanggapi dan mengenali perasaan secara tepat.Kecerdasan ini merupakan prasyarat dasar untuk menggunaka kecerdasan intelektual secara efektif.

Menurut Goleman, (2015 : 45)

mengatakan kecerdasan emosional yaitu suatu hal yang memotivasi diri sendiri, individu untuk bertahan menghadapi suatu frustasi diri yang akan mengendalikan hati atau melebihi suatu kecemasan berupa tingkat stress yang akan dijaga untuk tidak melumpuhkan kemampuan berpikir, berdoa dan berempati.Sedangkan,Kecerdasan emosional adalah serangkaian kemampuan, kompetensi, dan kecakapan nonkognitif yang mempengaruhi seseorang untuk mempengaruhi seseorang untuk berhasil mengatasi tuntutan dan tekanan lingkungan (Bar-on dalam Uno, 2006:69)

Istilah kecerdasan emosi pertama kali diungkapkan oleh dua orang ahli pada tahun 1990, yaitu Salovey dan Mayer dalam Uno (2006: 68) untuk menerangkan jenis-jenis kualitas emosi yang dianggap penting untuk mencapai keberhasilan. Kualitas emosional memiliki beberapa jenis yaitu : (1) sikap hormat, (2) diskusi (3) mengendalikan amarah, (4) ketekunan, (5) kemampuan menyesuaikan diri, (6) kesetiakawanan, (7) kemampuan memecahkan masalah antarpribadi (8) kemampuan kemandirian, mengungkapkan dan memahami perasaan, (10) keramahan dan, (11) empati.

Stein dan E. Book dalam Uno (2006:

69) mengetakan bahwa kecerdasan emosional merupakan suatu pengelaian perasaan yang dilakukan secara mendalam untuk membantu perkembangan intelektual dan emosioanal serta mengenali kemampuan untuk memahami suatu perasaan dan maknanya.

Sementara itu, Sukmadinata (2007: 97) mengatakan bahwa orang yang memiliki kecerdasan emosional yang tinggi adalah seseorang yang mampu mengendalikan diri, memelihara dan dan memacu motivasi untuk terus berupaya dan tidak mudah menyerah, mampu mengendalikan stress, mampu menerima kenyataan, dan dapat merasakan kesenangan meskipun dalam kesulitan.

Cooper dan Sawaf (2006: 69) menjelaskan kecerdasan emosional memiliki keterkaitan dan kecerdasan lainnya untuk saling melengkapi satu sama lainnya, akan tetapi penalaran logika untuk 
menyelaraskan sutau yang keliru dari prosessss teknologi dengan sentuhan manusiawi.

Berdasarkan uraian diatas, kecerdasan emosional dalam penelitian ini merupakan serangkaian kemampuan pribadi yang dimiliki siswa untuk mengatur emosinya. Kecerdasan emosional dapat menuntun siswa dalam bertingkah laku dan meraih keberhasilan yang dilakukan dengan beberapa cara. Cara-cara tersebut ialah mengenali emosi diri, mengelola emosi, memotivasi diri sendiri, mengenali emosi orang lain (empati), dan kemampuan untuk membina hubungan (kerja sama) dengan orang lain atau sesama siswa.

\section{b. Komponen-komponen kecerdasan emosional}

Kecerdasan emosi terbagi dalam bebrapa komponen yang membentuknya. Solvey dalam Uno (2006: 74-75) mengklasifikasikan kecerdasan emosi dalam lima kemampuanutama, yaitu:

a. Membina hubungan, individu yang terampil dalam membina hubungan dengan orang lain dapat menjalin hubungan dengan orang lain dengan cukup lancer, peka membaca reaksi dan perasaan orang lain, mampu memimpin dan mengirganisasi, serta pandai dalam menangani perselisihan yang muncul dalam setiap kegiatan.

b. Mengenali emosi diri adalah kesadran diri yang mengenali perasan sewaktu perasaan itu terjadi. Kesadaran diri adalah perhatian terus-menerus terhadap keadaan batin seseorang.

c. Mengenali emosi orang lain, yaitu kemampuan empati yaitu kemampuan untuk mengetahui bagaimana perasaan orang lain ikut berperan dalam persaingan kehidupan.

d. Mengelola emosi berhubungan dengan kemampuan untuk menghibur diri sendiri, melepaskan kecemasan, kemurungan atau ketersinggungan, dan akibat-akibat dari yang di timbulkan karena gagalnya keterampilan emosi dasar.

e. Memotivasi diri sendiri kemampuan menata emosi sebagai alat untuk mencapai tujuan dalam kaitan untuk memberi perhatian, untuk memotivasi diri sendiri, dan untuk berekreasi.

Goleman (2015: 272-273) terdapat tujuh kemampuan penting selain komponenkomponen yang berkaitan dengan kecerdasan emosional, diantaranya adalah:

a. Keyakinan: perasaan kendali dan penguasaan individu terhadap tubuh, perilaku, dan dunia. Perasaan mengenai berhasil tidaknya individu pada hal yang sedang dikerjakannya.

b. Rasa ingin tahu: perasaan bahwa menyelidiki segala sesuatu bersifat positif dan menimbulkan kesenangan.

c. Niat: hasrat dan kemampuan untuk berhasil dan bertindak berdasarkan niat dengan tekun. Hal ini berkaitan dengan perasaan terampil dan perasaan efektif.

d. Kendali diri: kemampuan untuk menyesuaikan dan mengendalikan tindakan dengan cara yang sesuai dengan usia individu, merupakan suatu rasa kemdali yang bersifat batiniah.

e. Keterkaitan: kemampuan untuk melibatkan diri dengan orang lain berdasarkan pada perasaan saling memahami.

f. Kecakapan berkomunikasi: keyakinan dan kemampuan verbal untuk bertukar gagasan, perasaan, dan konsep dengan orang lain.

g. Kooperatif: kemampuan untuk menyeimbangkan kebutuhan diri sendiri dengan kebutuhan orang lain dalam kegiatan kelompok.

Apabila siswa mampu menguasai kemampuan tersebut dengan baik, maka siswa dapat dikatakan memiliki keyakinan pada diri sendiri, memiliki minat, tahu bagaimana mengendalikan keinginan untuk berbuat yang tidak baik, mampu 
menunggu, mengikut petunjuk, dan mengacu pada guru untuk mencari bantuan. Mengungkapkan apa yang dibutuhkannya saat bergaul bersama siswa-siswa lain. Hal ini akan mempermudah siswa untuk mengelola emosi, memotivasi diri, dan membina hubungan dengan orang lain.

Berdasarkan teori yang diungkapkan oleh Salovey dalam Uno (2006: 74-75) peneliti mengambil komponen-komponen utama kecerdasan emosi sebagai faktor untuk mengembangkan instrument kecerdasan emosional, karena faktor-faktor tersebut dapat menjadi acuan peneliti dalam menentukan instrument kecerdasan emosional, sehingga peneliti dapat mengetahui kecerdasan emosional yang dimiliki oleh siswa. Komponen tersebut yaitu mengenali emosi diri, mengelola emosi, memotivasi diri sendiri, mengenali emosi orang lain (empati), dan membina hubungan dengan orang lain

\section{c. Faktor-faktor mempengaruhi kecerdasan emosional}

Kecerdasan emosional memiliki beberapa faktor yang dapat mempengaruhi.Goleman dalam casmini (2007: 23) menjelaskan bahwa terdapat dua faktor yang mempengaruhi kecerdasan emosional. Faktor tersebut menjadi faktor inernal dan faktor eksternal, yaitu sebagai berikut:

a. Faktor internal

Faktor internal merupakan faktor yang timbul dari dalam diri yang dipengaruhi oleh keadaan otak emosional individu dan hal-hal lain yang berada pada otak emosional.

b. Faktor eksternal

Faktor eksternal merupakan faktor yang datang dari luar individu dan mempengaruhi individu untuk mengubah sikap.Pengaruh luar yang bersifat individu individu dapat secara perorangan, dan secara kelompok.
Berdasarkan uraian diatas, dapat disimpulkan bahwa faktor-faktor yang mempengaruhi kecerdasan emosi adalah faktor internal dan faktor eksternal.Faktor internal yaitu faktor yang berasal dari dalam diri individu.Faktor internal ini membantu individu dalam mengelola, mengontrol, dan mengendalikan emosinya agar dapat terkoordinasi dengan baik dan tidak menimbulkan masalah bagi dirinya dan oang lain. Sedangkan, faktor eksternal yaitu faktor yang berasal dari luar diri individu. Faktor eksternal membantu individu untuk mengenali emosi orang lain, sehingga individu dapat belajar mengenai berbagai macam emosi yang dimiliki orang lain, membantu individu untuk merasakan emosi orang lain dengan keadaan yang menyertainya.

\section{Hakekat Belajar}

\section{a. Pengertian Belajar}

Belajar merupakan bentukan kata yang sudah umum untuk kaliangan masyarakat.Sama halnya dengan kata "belajar" untuk kalangan mahasiswa.Hal ini karena merupakan bagian lapisan masyrakat yang tidak dapat terpisahkan dilingkungan formal sbeab dilkaukan secara forml sesusai dengan kegiatan yang dilakukan guru dengan siswa di pendidikan.

Belajar tidak dapat dipisahkan dalam kehidupan masyarakat karena dapat mengembangkan kemampuan kognitif, psikomotorik, dan ketrampilan.Hal ini untuk mewujukan generasi penerus yang aman dan stabil.Selain itu, belajar merupkan hal yang dilakukan sepanjang hayat dan tidak ada hentinya.

Menurut Slameto ( 2010:2 ) mengatakan bahwa belajar merupakan suatu kegiatan untuk memperoleh perubahan secara keselruuhan sebab mengalami perubahan sikap individu dari pengalamannya saat berinteraksi dengan lingkungannya.

Menurut Winkel dalam susanto ( 2016:4 ) menyatakan bahwa: "belajar adalah suatu aktivitas mental yang berlangsung secara aktif bagi seseorang dengan situasi lingkunggannya untuk 
menghaasilkan perubahan pengetahuan dan sikap yang dinamis dan berbekas".

Berdasarkan ahli tersebut, dapat disimpullkan bahwaa belajar adalah suatu bagian untuk mendapatkan perubahan dari individu terhadap pengalamannya dalam berinteraksii dengan lingkungannya maupun seseama individue, maka menciptakan sikap yang dinamis dan berbakass.

\section{b. Pengertian Hasil Belajar}

Pada umumnya hasil belajar merupakan hasil interaksi dari berbagai faktor, secara garis besar.Factor-faktorr mempengaruhui hasill dalam belajar ada dua yaitu internal dan eksternal.

Pengertian hasil belajar Menurut Purwanto, ( 2017:34 ) menjelaskan bahwa: Hasil belajar merupakan perilaku akibatbelajar. Perubahan itu dilakukan dalam setiap pembelajaran sehingga menciptakan tujuan dari pendidikan yang berkembang.Hal ini dilakukan karena sistem pembelajaran tidak dilakukan secara individu ataupun tunggal melainkan domain.Akan tetapi, dissesuaikan dengan perubahan dalam pendidikan yang mencapai dari tujuan pendidikan.

Sedangkan menurut Diniati dan Mudjiono ( 2013:200 ) mengatakan bahwa: "hasil belajar adalah sutau hal untuk mengembangkan proses dari nilai melalui kegiatan pembelajran untuk menentukan pengukuraan hasil belajarr.

Menurut teori dari ahli tersebut dapat disimpilkan bahwa siswa akan memperoleh perubahan dari belajar melalui penilaian pembelajaran yang dilakukan di dalam kelas.

\section{c . Faktor-Faktor yang Mempengaruhi Hasil Belajar}

Dalam belajar ada banyak yang melajar adapun faktor-faktor yang mepengaruhi seseorang anak atau siswa dalam melakukan aktifitas belajar adapun fakttor-faktor yang mempeengaruhi hasil belajar terbagi 2 yaitu internal dan eksternal seperti yang dikemukakan Slameto ( 2010:54):

1. Faktor internal a. Faktor jasmaniah meliputi dari kesehatan, cacat tubuh.

b. Faktor psikologi meliputi dari intelegeensi, perhatiian, bakat, minat.

c. Faktor kelelahan

2. Faktor eksternal

a. Faktor keluarga meliputi dari didikan orangtua , sosioalisasi dalam keluarga, keadaan ekonimi keluarga, pengeertian orangtua, laatar belkang kbudayaan.

b. Faktor sekolah terdiri dari sistem metode atau cara mengajar, kurikulum, relasy antar gueru dengan syswa, relasi siswa dengan siswa/i

c. Faktor masyarakat terdiri dari suatu kegiatan siswa dalam bermasyarakat, Koran atau majalah.

Sedangkan menurut Susanto (2013:12-13) bahwa faktor-faktor yang memengaruhi hasil belajar antara lain:

a. Faktor internal adalah suatu kemampuan diri untuk memiliki keinginan belajar dengan memiliki sikap, minat, kepercayaan diri dalam belajar, mental dan psikolog yang sehat, dan kebiasaan.

b. Faktor eksternal adalah suatu yang berasal dari lingkungan atau diluar diri siswa yang akan berkaitan atau berkesinambungan dengan hasil beljar, seperti kurnagnya perhatian orangtua atau keharmonisan dalam keluarga, sistem ekonomi atau keuangan keluarga.

Dari kutipan ahli dapat disimpulkan mengenai faktr-fakktor mempengaruhi hasil dalam beljar dan tercipta dengan baik apabila terjaminnya kesehatan siswa, kenyamanan dalam proses belajar mengajar, sarana dan prasarana 
yang memadai, serta program atau kurikulum yang tertata baik dan supaya tercipta juga proses belajar mengajar, sarana dan prasarana yang memadai, sertta program atau kurikulum yang tertata dengan baik. Dengan demikian sebagai seorang guru harus memiliki strategi yang tepat untuk menghadirkan suasana belajar yang kondusif bagi setiap siswanya.

\section{d . Tujuan Pembelajaran PKn}

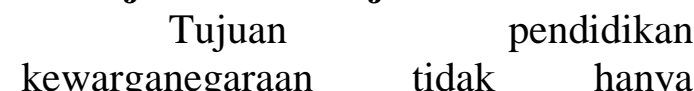
meningkatkan kemampuan intelektual saja namun nilai budaya, perilaku dan akhlak perlu ditanamkkan dalam peserta didik, sehingga proses pembelajaran dalam pendidikan itu hanya menghasilkan manusia yang berilmu tinggi namun juga manusia yang memiliki budi pekerti dan akhlak yang tinggi pula. Untuk ulasan tersebut maka diperlukan pendidikan kewarganegaraan yang memberikan pengetahuan normanorma dan etika yang berazaskan pancasila.

Guru yang memegang peranan penting dan meningkatkan hasil belajar.Peserta didik setelah ia menerima pengalaman pembelajaran. Sejumlah pengalaman yang diperoleh peserta didik mencakup ranah kognitif, afektif, dan psikometrik. Hasil belajar juga merupakan gambaran kualitas tertentu, untuk mencapai hasil belajar yang baik harus terjadi kerja sama yang baik antara guru dan siswa, guru yang memegang peranan penting dan meningkatkan hasil belajar.

Tabel 4.1 Distribusi Frekuensi Data Ubahan Kecerdasan Emosional (X)

\begin{tabular}{|l|l|c|c|c|}
\hline No & Rentangan & $\begin{array}{l}\text { Frekuensi } \\
\text { Observasi }\end{array}$ & $\begin{array}{l}\text { Frekuensi } \\
\text { Relatif }(\%)\end{array}$ & Kategori \\
\hline 1 & $56-60$ & 11 & $11 \%$ & Sangat Tinggi \\
\hline 2 & $51-55$ & 21 & $21 \%$ & Tinggi \\
\hline 3 & $46-50$ & 27 & $27 \%$ & Sedang \\
\hline 4 & $51-45$ & 34 & $34 \%$ & Rendah \\
\hline 5 & $<40$ & 7 & $7 \%$ & Sangat Rendah \\
\hline
\end{tabular}

Dalam sekolah guru bertanggung jawab dalam membimbing serta mendidik anak didik dalam kehidupan sehari-hari. Guru lah yang paling utama yang memberikan dorongan serta bimbingan untuk melatih anak didik di sekolah.

Untuk mencapai hasil belajar yang baik salah satunya adalah interaksi edukatif guru harus lah baik kepada siswa dalam belajar. Interaksi merupakan salah satu penunjang untuk memudahkan siswa untuk berkonsentrasi dalam kegiatan proses belajar mengajar. Maka dengan itu kita bisa melihat hubungan interaksi edukatif guru dengan hasil belajar sangat berdampak terhadap hasil belajar siswa.

\section{METODE PELAKSANAAN}

Jenis penelitian ini adalah penelitian kuantitatif dengan menggunakan uji hubungan antara variable-variabel yang akan diteliti dengan menggunakan metode deskriptif.

\section{HASIL DAN PEMBAHASAN}

A. Hasil Penelitian

1. Deskripsi Hasil Penelitian

a. Data Ubahan Kecerdasan Emosional Siswa (X)

Berdasarkan data yang diperoleh dari hasil penelitian dengan jumlah responden 100 orang dengan skor tertinggi 60 dan skor terendah 36 dengan rata-rata $M$ $=(47,55)$ dan standar deviasi SD $=(5,855)$. Data ubahan kecerdasan emosional (X) dapat dilihat pada tabel 4.1. Perhitungannya dapat dilihat pada lampiran. 


\begin{tabular}{|l|l|l|l|}
\hline & 100 & $100 \%$ & \\
\hline
\end{tabular}

Berdasarkan tabel di atas dapat disimpulkan kecerdasan emosional Siswa SMA Negeri Sipahutar Tapanuli UtaraT.A 2019/2020 dikategorikan "rendah".

b. Data Ubahan Hasil Belajar PKn (Y)

Berdasarkan data yang diperoleh

dari hasil penelitian dengan jumlah responden 100 orang dengan skor tertinggi 67 dan skor terendah 50 dengan rata-rata $M$ $=(60,09)$ dan standar deviasi SD $=(4,492)$. Data ubahan hasil belajar PKn (Y) dapat dilihat pada tabel 4.2. Perhitungannya dapat dilihat pada lampiran.

Tabel 4.2 Distribusi Frekuensi Data Ubahan Hasil Belajar PKn (Y)

\begin{tabular}{|l|l|c|c|c|}
\hline No & Rentangan & $\begin{array}{l}\text { Frekuensi } \\
\text { Observasi }\end{array}$ & $\begin{array}{l}\text { Frekuensi } \\
\text { Relatif }(\%)\end{array}$ & Kategori \\
\hline 1 & $65-67$ & 19 & $19 \%$ & Sangat Tinggi \\
\hline 2 & $62-64$ & 22 & $22 \%$ & Tinggi \\
\hline 3 & $59-60$ & 26 & $26 \%$ & Sedang \\
\hline 4 & $56-58$ & 16 & $16 \%$ & Rendah \\
\hline 5 & $<56$ & 17 & $17 \%$ & Sangat Rendah \\
\hline & & 100 & $100 \%$ & \\
\hline
\end{tabular}

Berdasarkan tabel di atas disimpulkan hasil belajar PKn Siswa SMA Negeri Sipahutar Tapanuli UtaraT.A 2019/2020 dikategorikan "sedang".
2. Uji Persyaratan Analisa

a. Uji Normalitas

Uji normalitas variabel pada penelitian ini menggunakan rumus $\mathrm{Chi}$ kuadrat $\left(\mathrm{X}^{2}\right)$, dengan syarat normal apabila $\mathrm{X}_{\mathrm{h}}{ }^{2}<\mathrm{X}_{\mathrm{t}}^{2}$ pada taraf signifikan $5 \%$ dengan derajat kebebasan.

Tabel 4.4 Ringkasan uji normalitas sebaran data penelitian

\begin{tabular}{|c|c|c|c|c|}
\hline Variabel penelitian & $\mathrm{Dk}$ & $\mathrm{X}_{\mathrm{h}}{ }^{2}$ & $\mathrm{X}_{\mathrm{t}}^{2}$ & Kurva \\
\hline Kecerdasan Emosional Siswa $(\mathrm{X})$ & 100 & 63,099 & 124,342 & Normal \\
\hline Hasil Belajar (Y) & 100 & 14,306 & 124,342 & Normal \\
\hline
\end{tabular}

Berdasarkan tabel diatas, uji normalitas $\mathrm{X}_{\mathrm{h}}{ }^{2}$ data setiap variabel diperoleh variabel kecerdasan emosional siswa (X) $\mathrm{X}_{\mathrm{h}}{ }^{2}$ $=63,099, \quad \mathrm{X}_{\mathrm{t}}^{2}=124,342 \quad\left(\mathrm{X}_{\mathrm{h}}^{2}<\mathrm{X}_{\mathrm{t}}^{2}\right)$ $(63,099<124,342)$, dan variabel motivasi belajar siswa (Y) ) $\mathrm{X}_{\mathrm{h}}^{2}=36,713 \mathrm{X}_{\mathrm{t}}^{2}=$ $124,342\left(\mathrm{X}_{\mathrm{h}}^{2}<\mathrm{X}_{\mathrm{t}}^{2}\right)(36,713<124,342)$, pada taraf signifikan $\alpha=0,05$. Dengan demikian dapat disimpulkan distribusi data kedua variabel penelitian berdistribusi normal.

b. Uji Linearitas
Penelitian ini memiliki dua variabel penelitian. Satu variabel bebas dan satu variabel terikat, dalam variabel bebas diduga dapat mempengaruhi variabel terikat. Oleh karena itu perlu diuji kelinierannya dengan menerapkan rumus regresi $\mathrm{X}$ dan $\mathrm{Y}$, yaitu $\mathrm{Y}=40,479+0,412 \mathrm{X}$ pada taraf $5 \%$. Dengan menggunakan rumus tersebut dapat diketahui bahwa data kecerdasan emosional linear dengan hasil 
belajar Pkn siswa Siswa SMA Negeri Sipahutar Tapanuli Utara T.A 2019/2020.

3. Uji Kecenderungan a. Kecenderungan

Kecerdasan

Tabel KecenderunganKecerdasan Emosional Siswa (X)

\begin{tabular}{|c|c|c|c|c|}
\hline No & Kelompok & F absolut & F relative & Kategori \\
\hline 1 & $>54$ & 15 & 15 & Sangat Tinggi \\
\hline 2 & $51-54$ & 17 & 17 & Tinggi \\
\hline 3 & $47-50$ & 21 & 21 & Sedang \\
\hline 4 & $42-46$ & 31 & 31 & Rendah \\
\hline 5 & $<42$ & 16 & 16 & Sangat Rendah \\
\hline & & 100 & $100 \%$ & \\
\hline
\end{tabular}

Dari tabel diatas dapat disimpulkan kecenderungan kecerdasan emosional Siswa SMA Negeri Sipahutar Tapanuli

b. Kecenderungan Hasil Belajar PKn
UtaraT.A 2019/2020 dikategorikan cenderung "rendah" $(31 \%)$.

Tabel 4.6 Kecenderungan Hasil Belajar PKn (Y)

\begin{tabular}{|l|l|l|l|l|}
\hline No & Kelompok & F absolut & F relative & Kategori \\
\hline 1 & $>64$ & 19 & 19 & Sangat Tinggi \\
\hline 2 & $61-64$ & 28 & 28 & Tinggi \\
\hline 3 & $58-60$ & 29 & 29 & Sedang \\
\hline 4 & $55-60$ & 11 & 11 & Rendah \\
\hline 5 & $<55$ & 13 & 13 & Sangat Rendah \\
\hline & & 100 & $100 \%$ & \\
\hline
\end{tabular}

Dari tabel diatas dapat disimpulkan kecenderungan hasil belajar Pkn siswa Siswa SMA Negeri Sipahutar Tapanuli Utara T.A 2019/2020 cenderung "sedang"(29\%).

\section{Uji Hipotesis Penelitian}

Uji Hipotesis kecerdasan emosional (X) dengan hasil belajar PKn (Y) menggunakan rumus - rumus korelasi product moment. Hasil analisis korelasi diperoleh koefisien korelasi kecerdasan emosional (X) dengan hasil belajar PKn (Y) diperoleh $\mathrm{r}_{\mathrm{xy}}$ sebesar 0,537 dikonsultasikan terhadap tabel kritik moment pada taraf signifikan 5\% dengan $\mathrm{N} 100$ diketahui $\mathrm{r}_{\text {tabel }}$ $=\quad 0,195$. Sehingga $\quad r_{\text {hitung }}>r_{\text {tabel }}$ $(0,537>0,195)$. Hal ini menunjukkan ada hubungan kecerdasan emosional dengan hasil belajar PKN Siswa SMA Negeri
Sipahutar Tapanuli Utara T.A 2019/2020.

Uji signifikan korelasi dilakukan dengan menggunakan uji statistik (uji t) dimana $t_{\text {hitung }}=6,304$ dan $t_{\text {tabel }}=1,660$ pada taraf signifikan $t_{0,95}$ di peroleh $t_{\text {hitung }}>t_{\text {tabel }}$ $(6,304>1,660)$. Hal ini menunjukkan ada hubungan yang signifikan antara kecerdasan emosional dengan hasil belajar PKN Siswa SMA Negeri Sipahutar Tapanuli UtaraT.A 2019/2020 kebenarannya dapat diterima.

\section{B. Pembahasan Hasil Penelitian}

Hasil penelitian menunjukkan bahwa, ada hubungan yang signifikan antara kecerdasan emosional dengan hasil belajar PKN Siswa SMA Negeri Sipahutar Tapanuli Utara T.A 2019/2020 kebenarannya dapat diterima. 
PKn merupakan salah satu pelajaran yang penting bagi para siswa terdapat dalam tujuan Pendidikan Kewarganegaraan tidak hanya meningkatkan kemampuan intelektual saja namun nilai budaya, perilaku, akhlak perlu ditanamkan dalam peserta didik, sehingga proses pembelajaran dalam pendidikan itu hanya menghasilkan manusia yang berilmu tinggi namun juga manusia memiliki budi pekerti dan akhlak yang tinggi pula.

Hasil belajar yang baik dapat diraih dengan belajar sungguh - sungguh.Ada beberapa faktor yang mempengaruhi hasil belajar, di antaranya faktor tubuh (jasmani) dan faktor psikologis.

Kecerdasan emosional merupakan kemampuan individual untuk memotivasi diri sendiri, bertahan menghadapi frustasi, mengendalikan dorongan hati dan tidak melebih - lebihkan kesenagan, mengatur suasana hati dan menjaga agar beban stress melumpuhkan kemampuan berpikir, berempati, dan berdoa.

Oleh karena itu, kecerdasan emosi siswa yang rendah, harus disesuaikan dengan berat ringannya materi, jika materi pelajaran sangat berat dipaksakan kepada siswa yang mempunyai kecerdasan emosi yang rendah, makan akan membuat siswa malas tidak semangat untuk belajar.

\section{SIMPULAN}

Berdasarkan hasil penelitian analisis data yang telah diperoleh dengan berorientasikan pada masalah - masalah dan tujuan dalam penelitian ini, maka penulis menarik kesimpulan sebagai berikut:

1. Kecenderungan kecerdasan emosional Siswa SMA Negeri Sipahutar Tapanuli UtaraT.A 2019/2020 dikategorikan cenderung "rendah" (31\%).

2. Kecenderungan hasil belajar Pkn siswa Siswa SMA Negeri Sipahutar Tapanuli Utara T.A 2019/2020 cenderung "sedang"(29\%).
3. Ada hubungan kecerdasan emosional dengan hasil belajar PKN Siswa SMA Negeri Sipahutar Tapanuli UtaraT.A 2019/2020diperoleh $r_{\text {hitung }}=0,537$ $\mathrm{r}_{\text {tabel }}=0,195$. Sehingga $\left(\mathrm{r}_{\text {hitung }}>\mathrm{r}_{\text {tabel }}\right)$ $(0,537>0,195)$.

4. Ada hubungan yang signifikan antara kecerdasan emosional dengan hasil belajar PKN Siswa SMA Negeri Sipahutar Tapanuli UtaraT.A 2019/2020 diperoleh $\mathrm{t}_{\text {hitung }}=6,304$ dan $\mathrm{t}_{\text {tabel }}=1,660$ $\left(t_{\text {hitung }}>t_{\text {tabel }}\right)(6,304>1,660)$.

\section{Saran}

Dalam upaya meningkatkan moral siswa, hendaknya siswa diberikan kesempatan untuk mempelajari berbagai moral dari berbagai literatur dan ditunjukkan melalui kepribadian yang dimiliki seornag guru.Mengingat keterbatasan penelitian ini, maka disarankan bagi peneliti lainnya untuk mengadakan penelitian lebih lanjut, guna menemukan faktor lain yang lebih dominan dalam memberikan kontribusi terhadap hasil praktik dengan mengikutsertakan variabel yang lebih kompleks.

\section{DAFTAR PUSTAKA}

Ahmad Susanto.2016. Teori dan Pembelajaran.Prenada Media Group. Jakarta

Arikunto, Suharsimi.2013.prosedur penelitian, Rineka Cipta. Jakarta

Aunurrahman.2012. belajar dan pembelajaran.PT. Alfabeta. Bandung

KBBI .2007. Kamus Besar Bahasa Indonesia.PT Balai Pustaka. Jakarta

Permendiknas No. 22 Tahun 2006 tentang Standar is Purwanto. 2014. Evaluasi Hasil Belajar. Pustaka Pelajar. Yogyakarta.

Purwanto. 2014. Evaluasi Hasil Belajar. Pustaka Pelajar. Yogyakarta. 
Slameto. 2013. Belajar dan Faktorfaktor yang Mempengaruhinya. Rineka Cipta. Jakarta

Sugiyono.2016. Metode Penelitian Pendidikan.Alfabeta. Bandung

Undang-undang.2003. Undang-undand RI No 20 Tahun 2003 Tentang SistemPendidikan

Nasional.Depdiknas RI. Jakarta

Uno, Hamzah B.2006. Orientasi Baru dalam Psikologi Pembelajaran.PT.

BumiAksara. Jakarta 